\title{
En innføring i depresjonsvurdering med PHQ-9
}

\author{
Tomas F. Langkaas \\ Even Rognan \\ Vestre Viken HF
}

\author{
Sverre U. Johnson \\ Universitetet i Oslo og Modum Bad
}

\section{An introduction to assessment of depression with $P H Q-9$}

\begin{abstract}
Assessment of depression is a routine task in clinical practice in Norway. National guidelines (Helsedirektoratet, 2009) recommend the use of measurement instruments in assessment of depression. PHQ-9 is widely used in research and practice. The official PHQ-9 manual provides practical guidance on interpreting test results with the use of clinical cutoff scores and a diagnostic algorithm for DSM-IV. With background from clinical practice and research, we summarize and provide guidance on the practical use of PHQ-9 beyond what the official PHQ-9 manual offers, applied to a Norwegian context. We provide a general introduction to diagnostic assessment of depression and the limited role of measurement instruments in such assessments. We describe how the original diagnostic algorithm can be adapted to ICD-10 criteria, we describe how to apply clinical significance to use PHQ-9 as a feedback instrument to monitor treatment progress, and we describe how to interpret results with missing answers. Finally, we discuss the shortcomings of relying on measurement instruments in assessment of depression and conclude that PHQ-9 is better suited in ordinary practice than other instruments recommended in the national guidelines.
\end{abstract}

Keywords: PHQ-9, diagnostic assessment, progress and outcome monitoring.

Depresjon er en av de vanligste psykiske lidelsene (World Health Organization, 2017). Vurdering av depresjon er følgelig en rutineoppgave i klinisk psykologisk arbeid i Norge, også fordi depresjon er en relevant risikofaktor å kartlegge ved vurdering av selvmordsrisiko (Helsedirektoratet, 2008). Nasjonale retningslinjer for diagnostisering og behandling av voksne med depresjon i primær- og spesialisthelsetjenesten (Helsedirektoratet, 2009) anbefaler bruk av strukturerte kartleggingsverktøy ved vurdering av dep-

Tomas Formo Langkaas, Poliklinikken sentrum, Drammen DPS. Even Rognan, Poliklinikken sentrum, Drammen DPS. Sverre Urnes Johnson, Psykologisk institutt, Universitetet i Oslo og Forskningsinstituttet, Modum Bad.

PHQ-9 ble opprinnelig utviklet med økonomisk støtte fra legemiddelfirmaet Pfizer. Forfatterne har ingen tilknytning til Pfizer.

Forfatterne ønsker å takke Pål Nielsen Glad og anonyme fagfeller for nyttige innspill på tidligere utkast av denne artikkelen.

Adresse for korrespondanse er: Tomas F. Langkaas, Drammen DPS, Vestre Viken HF, Postboks 800, 3004 Drammen. E-post: tomas.langkaas@,gmail.com

Preprint publisert under Creative Commons CC BY 4.0. https://psyarxiv.com/8jwc7 resjon. I klinisk praksis er det i hovedsak tre aktuelle bruksområder for slike verktøy: (1) som forhåndskartlegging (screening) for å identifisere pasienter med mulig udiagnostisert depresjon, (2) for strukturert kartlegging av symptomkriterier ved diagnostisk vurdering av depresjon og (3) som kvantitativt mål på grad av depresjonssymptomer i vurdering av behandlingsutvikling. Et aktuelt alternativ i arbeidet med alle disse tre områdene er PHQ-9 ${ }^{1}$ (Kroenke, Spitzer \& Williams, 2001).

For praktisk bruk gir den offisielle instruksjonsmanualen til PHQ-9 (Pfizer, u.å.) begrenset informasjon. Den beskriver hvordan svarene på PHQ-9 kan summeres og sammenliknes med kliniske grenseverdier for å sannsynliggjøre mulig depresjon. I tillegg be-

\footnotetext{
${ }^{1}$ PHQ-9 er betegnelsen på depresjonsmodulen i Patient Health Questionnaire (PHQ; Spitzer, Kroenke \& Williams, 1999) og ikke en 9-ledds forkortet versjon av PHQ. Betegnelsen PHQ-9 er slik sett ikke noen forkortelse, men et selvstendig navn, noe som også gjenspeiles i originalreferansen (Kroenke, Spitzer \& Williams, 2001).
} 
skriver manualen en diagnostisk algoritme for å sammenholde svarene med diagnostiske kriterier for depresjon i Diagnostic and Statistical Manual of Mental Disorders (4th ed.; DSM-IV; American Psychiatric Association, 1994). Så langt vi kjenner til, finnes det ikke noen eksisterende norsk instruksjonsmanual eller noen instruksjonsmanual som beskriver praktisk bruk av PHQ-9 utover det som allerede beskrives i den offisielle instruksjonsmanualen.

Med utgangspunkt i egen praktisk erfaring med utredning og behandling av depresjon i spesialisthelsetjenesten for voksne og egen bakgrunnskunnskap om forskning og praksis, sammenfatter vi her relevant praktisk informasjon utover det som er beskrevet i den offisielle instruksjonsmanualen for PHQ-9, tilpasset norske forhold. Vi beskriver hvordan strukturerte kartleggingsverktøy som PHQ-9 kan inngå som del av en helhetlig diagnostisk vurdering av depresjon; vi presenterer en diagnostisk algoritme tilpasset International Classification of Diseases, 10th Revision (ICD-10; World Health Organization, 1992), som er gjeldende diagnosesystem i Norge; vi viser hvordan PHQ-9 kan anvendes som tilbakemeldingsverktøy med bruk av klinisk signifikans (Jacobson \& Truax, 1991) og vi viser hvordan resultater på PHQ-9 også kan tolkes ved ufullstendig besvarte skjemaer. Avslutningsvis drøfter vi sentrale begrensninger ved bruk av strukturerte kartleggingsverktøy i vurdering av depresjon.

\section{Om PHQ-9}

Patient Health Questionnaire (PHQ; Spitzer, Kroenke \& Williams, 1999) ble opprinnelig utviklet

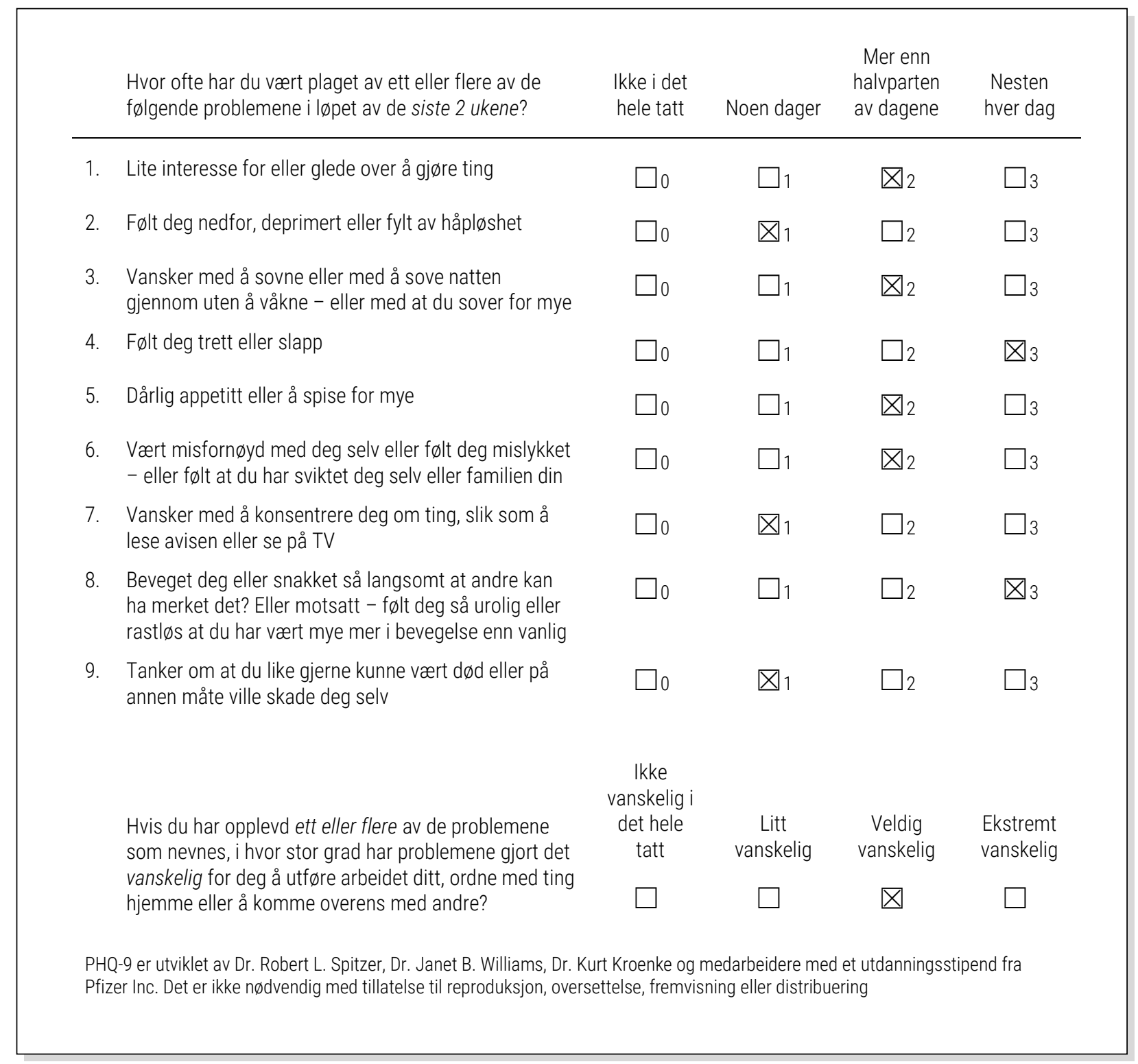

Figur 1. Eksempel på utfylt PHQ-9. 
for rask og effektiv kartlegging av fem vanlige psykiske helseproblemer i primærhelsetjenesten: Depresjon, angst, somatisering, alkohol- og spiseproblemer. PHQ-9 er depresjonsmodulen i PHQ, og er egnet som selvstendig spørreskjema for vurdering av depresjon. Skjemaet består av 9 spørsmål som er direkte knyttet til diagnosekriteriene i DSM-IV og skjemaet er mye brukt internasjonalt, både $\mathrm{i}$ forskning og i klinisk praksis. Eksempelvis anbefaler offisielle britiske retningslinjer å bruke PHQ-9 ved depresjonsvurdering (National Institute for Health and Care Excellence, 2011). American Heart Association anbefaler både PHQ-9 og kortversjonen PHQ-2 for vurdering av depresjon ved samtidig hjertesykdom (Lichtman m.fl. 2008). PHQ-9 brukes som standard spørreskjema for måling av depresjonsgrad og endring i depresjon i det engelske tjenestetilbudet Increased Access to Psychological Therapies (IAPT; National Collaborating Centre for Mental Health, 2018). Etter modell fra IAPT er PHQ-9 også brukt i tjenestetilbudet Rask psykisk helsehjelp her i Norge (Smith, Alves \& Knapstad, 2016). PHQ-9 er lisensfri og offisielle oversettelser for ulike språk, inkludert norsk bokmål, ligger fritt tilgjengelig på nett (https://www.phqscreeners.com).

Svarene på PHQ-9 kan sammenfattes på to måter (Pfizer, u.å.): (a) Verdien av avgitte svar kan summeres, noe som gir et kvantitativt mål på depresjonsgrad på en skala fra 0 til 27, eller (b) svarene kan sammenholdes direkte med diagnosekriterier for depresjon ved bruk av en diagnostisk algoritme. Måleegenskaper ved PHQ-9 er undersøkt i flere studier og utvalg. Kroenke, Spitzer og Williams (2001) oppgir intern konsistens på 0,83 og 48 timers test-retest reliabilitet på 0,84. En nyere psykometrisk metaanalyse (Levis, Benedetti \& Thombs, 2019) anslår sensitivitet på 0,88 og spesifisitet på 0,85 gitt en nedre klinisk grenseverdi (clinical cutoff score) på 10 og bruk av semistrukturert klinisk intervju som referansestandard.

\section{Diagnostisk vurdering av depresjon}

Depresjon er en tilstand som kjennetegnes av overdreven nedstemthet, nedsatt interesse og nedsatt glede $i$ en grad og et omfang som begrenser daglig funksjon. Tilstanden overskrider hva som kan forstås som en naturlig reaksjon på den aktuelle livssituasjonen. Depresjon er slik sett noe annet enn å være misfornøyd, trist eller ulykkelig som en naturlig og rimelig konsekvens av aktuelle omstendigheter.

Omfattende forskningsinnsats har hittil ikke bidratt til å identifisere noen pålitelige biologiske markører for depresjon (Strawbridge, Young \& Cleare, 2017) og det er omdiskutert om det er realistisk å skulle forklare depresjon som en underliggende biologisk tilstand (Bekhuis, Hartman, Boschloo, \& Lucassen, 2019). Klinisk vurdering av om diagnosekriteriene er oppfylt er det som er referansestandarden for å diagnostisere depresjon, slik kriteriene er beskrevet i ICD-10 og DSM-5. I praksis dreier dette seg om å vurdere tre spørsmål: (1) Er symptomer som kjennetegner depresjon tilstede, (2) bidrar symptomene til å forklare aktuell funksjonsbegrensning, og (3) er depresjon den beste forklaringen på symptombildet? Strukturerte kartleggingsverktøy - som PHQ-9 - kan primært bistå med å avklare det første spørsmålet.

\section{Tabell 1}

Symptomer på depressiv episode med tilhørende spørsmål $i$ PHQ-9 angitt $i$ parentes.

\begin{tabular}{|c|c|c|}
\hline $\begin{array}{l}\text { Diagnose- } \\
\text { system }\end{array}$ & ICD-10 & DSM-IV/DSM-5 \\
\hline $\begin{array}{l}\text { Symptom- } \\
\text { varighet }\end{array}$ & Minst 2 uker & Minst 2 uker \\
\hline \multirow[t]{3}{*}{$\begin{array}{l}\text { Kjerne- } \\
\text { symptomer }\end{array}$} & $\begin{array}{l}\text { Tap av interesse eller } \\
\text { glede (1) }\end{array}$ & $\begin{array}{l}\text { Tap av interesse eller } \\
\text { glede (1) }\end{array}$ \\
\hline & Nedstemthet (2) & Nedstemthet (2) \\
\hline & $\begin{array}{l}\text { Redusert energi eller økt } \\
\text { trettbarhet (4) }\end{array}$ & \\
\hline \multirow[t]{8}{*}{$\begin{array}{l}\text { Tilleggs- } \\
\text { symptomer }\end{array}$} & & $\begin{array}{l}\text { Redusert energi eller økt } \\
\text { trettbarhet (4) }\end{array}$ \\
\hline & Søvnvansker (3) & Søvnvansker (3) \\
\hline & Endret matlyst (5) & Endret matlyst (5) \\
\hline & $\begin{array}{l}\text { Tap av selvtillit og } \\
\text { selvfølelse }\end{array}$ & \\
\hline & $\begin{array}{l}\text { Overdreven selv- } \\
\text { bebreidelse eller } \\
\text { overdreven eller } \\
\text { upassende skyld- } \\
\text { følelse (6) }\end{array}$ & $\begin{array}{l}\text { Følelse av verdiløshet } \\
\text { eller overdreven eller } \\
\text { upassende skyld- } \\
\text { følelse (6) }\end{array}$ \\
\hline & $\begin{array}{l}\text { Konsentrasjons- } \\
\text { vansker (7) }\end{array}$ & $\begin{array}{l}\text { Konsentrasjons- } \\
\text { vansker (7) }\end{array}$ \\
\hline & $\begin{array}{l}\text { Endret psykomotorisk } \\
\text { tempo (8) }\end{array}$ & $\begin{array}{l}\text { Endret psykomotorisk } \\
\text { tempo (8) }\end{array}$ \\
\hline & $\begin{array}{l}\text { Selvmordsatferd eller } \\
\text { tilbakevendende tanker } \\
\text { om død eller } \\
\text { selvmord (9) }\end{array}$ & $\begin{array}{l}\text { Selvmordsatferd eller } \\
\text { tilbakevendende tanker } \\
\text { om død eller } \\
\text { selvmord (9) }\end{array}$ \\
\hline $\begin{array}{l}\text { Symptom- } \\
\text { krav }\end{array}$ & $\begin{array}{l}\text { Minst } 2 \text { kjerne- } \\
\text { symptomer og minst } 4 \\
\text { symptomer totalt }\end{array}$ & $\begin{array}{l}\text { Minst ett kjernesymptom } \\
\text { og minst } 5 \text { symptomer } \\
\text { totalt }\end{array}$ \\
\hline
\end{tabular}

Tabell 1 beskriver symptomer som kjennetegner depressiv episode i ICD-10, DSM-IV og DSM-5. Tabellen viser at symptomer på depresjon har vært 
uendret i de to siste versjonene av DSM, og at det er stor grad av sammenfall mellom DSM og ICD-10. Hovedkjennetegn ved depresjon - nedstemthet og tap av interesse eller glede - gjenspeiles i kjernesymptomer i begge diagnosesystemer. ICD-10 regner i tillegg redusert energi eller økt trettbarhet som et kjernesymptom, dette er kun et tilleggssymptom i DSM. De fleste tilleggsymptomene er også felles, med unntak av tap av selvtillit og selvfølelse som ikke inngår i DSM. Det er også en liten forskjell i hvilken kombinasjon av symptomer som er minstekrav for en depressiv episode. I ICD-10 holder det med 4 symptomer, der minst 2 må være kjernesymptomer. I DSM er det krav om 5 symptomer, minst ett av dem må være et kjernesymptom.

Det andre spørsmålet er om pasientens aktuelle funksjonsbegrensninger er knyttet til depresjonssymptomer. Dersom det ikke foreligger noen funksjonsbegrensning, eller den ikke er knyttet til depressive symptomer, faller naturlig nok grunnlaget for å vurdere depresjon bort.

Det siste spørsmålet - om depresjon er den beste forklaringen på symptombildet - er det som stiller størst krav til faglig vurdering og her kommer begrensningene ved strukturerte kartleggingsverktøy tydelig frem. Nedstemthet og mangel på tiltak og glede er en normalreaksjon på vanlige livsbelastninger og livskriser uten å være tegn på en sykdomstilstand som krever behandling av helsepersonell. På samme måte kan disse symptomene være en normalreaksjon på funksjonstap knyttet til andre samtidige lidelser, som for eksempel funksjonsbegrensende angsttilstander. Enkelte somatiske tilstander kan gi depresjonsliknende symptomer (slik som stoffskifteproblemer), det samme kan hjerneorganiske lidelser (som demens) eller aktiv bruk av rusmidler. Fysisk utmattelse og søvndeprivasjon kan også gi depresjonsliknende symptomer. Ved flere mulige forklaringer på aktuelle depresjonssymptomer er det derfor nødvendig med en vurdering av om disse tilstrekkelig kan forklare tilstandsbildet, eller om tilstanden bedre forstås som uttrykk for en samtidig depresjon. Det er følgelig alltid behov for faglig vurdering og strukturerte kartleggingsverktøy som PHQ-9 kan først og fremst bidra med å samle relevant informasjon som danner grunnlag for slik vurdering.

\section{PHQ-9 i praktisk bruk}

PHQ-9 besvares som et vanlig spørreskjema. Figur 1 viser et eksempel på et besvart skjema. Utfylling gjennomføres normalt i løpet av noen få minutter, og kan inngå som del av en konsultasjon eller fylles ut i forkant av en konsultasjon. For fremmedspråklige pasienter kan det være aktuelt å besvare spørsmålene på eget morsmål der det finnes tilgjengelige oversettelser. PHQ-9 kan også gjennomføres som et kort klinisk intervju med pasienter der det vurderes som mer aktuelt. Dette kan være i saker der man ønsker å være ekstra oppmerksom på at pasienten får med seg og forstår spørsmålene, som for eksempel hos pasienter med lesevansker, konsentrasjonsvansker, eller ved mulig redusert kognitiv funksjon.

Spørsmålene dreier seg om omfang av symptomer på depresjon i løpet av de siste to ukene. Hvert spørsmål har 4 faste svaralternativer, «Ikke i det hele tatt», «Noen dager», «Mer enn halvparten av dagene» og «Nesten hver dag». Svaralternativene gir henholdsvis $0,1,2$ og 3 poeng, og svarene i figur 1 kan slik sett gjengis i kortform som 212322131 . Tilleggsspørsmålet om funksjonsvansker bidrar med relevant informasjon for å vurdere om det foreligger noen funksjonsbegrensende tilstand eller ikke.
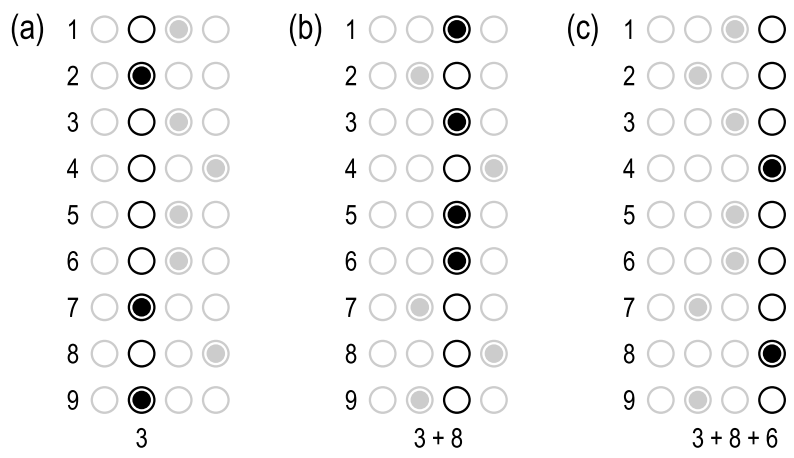

Figur 2. Summering av svarene fra figur 1 for å illustrere forhåndskartlegging (screening) med PHQ-9. Sammenlagt resultat av (a) alle ettpoengs svar, (b) alle topoengs svar, og (c) alle trepoengs svar blir her $3+8+6=17$. Omtrentlige nedre grenseverdier er henholdsvis 5, 10 og 20 for mulig mild, moderat og alvorlig depresjon. Et resultat på 17 sammenfaller med mulig moderat depresjon.

\section{Bruk av PHQ-9 for forhåndskartlegging (screening)}

For bruk ved forhåndskartlegging kan sammenlagt resultat av avgitte svar på PHQ-9 sammenliknes med kliniske grenseverdier for å gi en omtrentlig pekepinn på om, og i hvilken grad, en pasient er deprimert. Omtrentlige nedre grenseverdier er 5, 10 og 20 for mulig mild, moderat og alvorlig depresjon (Kroenke m.fl., 2001), mens resultater under 5 tyder på ingen depresjon. For kun dikotom vurdering av mulig depresjon 
er 10 en egnet nedre grenseverdi (Kroenke m.fl., 2001; Levis, Benedetti \& Thombs, 2019; Manea, Gilbody \& McMillan, 2012). Figur 2 illustrerer hvordan svar kan sammenfattes og vurderes på denne måten. (a)

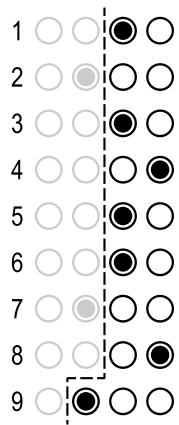

(b)

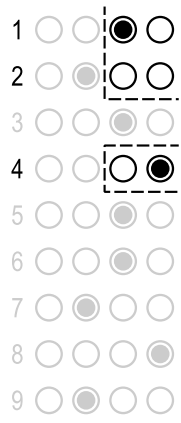

(c)

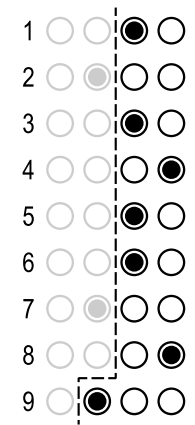

Figur 3. Vurdering av eksempelsvarene i figur 1 opp mot diagnostiske kriterier i ICD-10. (a) For hvert topoengs eller trepoengs svar regnes ett symptom å være tilstede, med unntak av spørsmål 9, hvor også ettpoengs svar teller. (b) Spørsmål 1, 2 og 4 angir kjernesymptomer, minst 2 av disse må være tilstede, slik som her. (c) Om nok kjernesymptomer er tilstede, telles totalt antall symptomer opp, her er totalt 7 tilstede. Mild og moderat depresjon krever minst 2 kjernesymptomer og henholdsvis 4 eller 6 symptomer totalt, alvorlig depresjon krever alle kjernesymptomer og minst 8 totalt. Her er kriterier for moderat depresjon oppfylt.

\section{Bruk av PHQ-9 for diagnostisk kartlegging}

Instruksjonsmanualen (Pfizer, u.å.) beskriver også en diagnostisk algoritme for å vurdere svarene på PHQ-9 direkte opp mot symptomkriteriene for depresjon i DSM. For hvert spørsmål besvart med «Mer enn halvparten av dagene» (topoengssvar) eller høyere regnes ett symptom å være tilstede, med unntak av spørsmål 9 hvor «Noen dager» (ettpoengssvar) regnes som tilstrekkelig. Som vist i tabell 1 stiller ICD-10 litt andre krav til symptomkombinasjon enn DSM, noe som gir grunnlag for en tilsvarende diagnostisk algoritme tilpasset ICD-10:

(1) For hvert spørsmål besvart med «Mer enn halvparten av dagene», eller mer (topoengssvar), regnes ett symptom å være tilstede. For spørsmål 9 er det nok med «Noen dager» (ettpoengssvar).

(2) Spørsmål 1, 2 og 4 angir kjernesymptomer ved depresjon. Minst 2 av disse må være tilstede ved mild og moderat depresjon, alle 3 må være tilstede ved alvorlig depresjon.
(3) I tillegg må minst totalt 4, 6 eller 8 symptomer være tilstede - inkludert kjernesymptomer - ved henholdsvis mild, moderat og alvorlig depresjon.

Figur 3 illustrerer vurdering av diagnostiske kriterier fra svarene i figur 1.

\section{Selvmordsrisiko}

Spørsmål 9 dreier seg om tanker om død eller selvskade og kan brukes som informasjon for å vurdere nærmere kartlegging av selvmordsrisiko. Dersom spørsmålet er ubesvart, eller svaret er noe annet enn «Ikke i det hele tatt», kan det være grunn til å undersøke dette spørsmålet mer. Det kan være en god rutine å alltid undersøke svaret på dette spørsmålet, og kanskje spesielt legge merke til om det er ubesvart.

\section{Bruk av PHQ-9 som tilbakemeldingsverktøy}

For pasienter som følges opp for depresjon kan summen av avgitte svar brukes som et kvantitativt mål på depresjonsgrad. Ved å svare på PHQ-9 gjentatte ganger underveis i behandling gir dette grunnlag for å følge med på behandlingsutvikling. Klinisk signifikans (Jacobson \& Truax, 1991) er en standardisert metode brukt i psykoterapiforskning for å anslå den praktiske kliniske betydningen av enkeltpasienters endring. Med utgangspunkt $i$ to tall som er beregnet fra normdata, (a) minste målbare endring og (b) grenseverdi som angir område for normalt funksjonsnivå, kan målt endring siden behandlingsstart kategoriseres som enten verre, uendret, bedre eller frisk (Langkaas, Johnson, Stenshorne, Collin-Tiller \& Vrabel, 2017). For PHQ-9 kan minste målbare endring anslås til \pm 6 og område for normal funksjon til $\leq 6$ (se Langkaas m.fl., 2017, for detaljer og beregningsgrunnlag). Sammenholdt med eget resultat ved behandlingsstart kan dermed en pasients aktuelle tilstand vurderes som

- verre ved økning på 6 poeng eller mer,

- uendret ved mindre enn 6 poengs endring,

- bedre ved nedgang på 6 poeng eller mer og siste resultat over 6 , eller

- frisk ved nedgang på 6 poeng eller mer og siste resultat lik 6 eller lavere. 
Tabell 2

Resultatområder for å vurdere klinisk signifikant endring av depresjon med PHQ-9. Tallene er basert på en minste målbar endring på 6 poeng og et normalt funksjonsområde med en øvre grenseverdi på 6.

\begin{tabular}{|c|c|c|c|c|}
\hline \multirow{2}{*}{$\begin{array}{c}\text { PHQ-9 ved } \\
\text { behandlingsstart }\end{array}$} & \multicolumn{4}{|c|}{ PHQ-9 resultatområder } \\
\hline & Frisk & Bedre & Uendret & Verre \\
\hline 0 & & & $0-5$ & $6-27$ \\
\hline 1 & & & $0-6$ & $7-27$ \\
\hline 2 & & & $0-7$ & $8-27$ \\
\hline 3 & & & $0-8$ & $9-27$ \\
\hline 4 & & & $0-9$ & $10-27$ \\
\hline 5 & & & $0-10$ & $11-27$ \\
\hline 6 & 0 & & $1-11$ & $12-27$ \\
\hline 7 & $0-1$ & & $2-12$ & $13-27$ \\
\hline 8 & $0-2$ & & $3-13$ & $14-27$ \\
\hline 9 & $0-3$ & & $4-14$ & $15-27$ \\
\hline 10 & $0-4$ & & $5-15$ & $16-27$ \\
\hline 11 & $0-5$ & & $6-16$ & $17-27$ \\
\hline 12 & $0-6$ & & $7-17$ & $18-27$ \\
\hline 13 & $0-6$ & 7 & $8-18$ & $19-27$ \\
\hline 14 & $0-6$ & $7-8$ & $9-19$ & $20-27$ \\
\hline 15 & $0-6$ & $7-9$ & $10-20$ & $21-27$ \\
\hline 16 & $0-6$ & $7-10$ & $11-21$ & $22-27$ \\
\hline 17 & $0-6$ & $7-11$ & $12-22$ & $23-27$ \\
\hline 18 & $0-6$ & $7-12$ & $13-23$ & $24-27$ \\
\hline 19 & $0-6$ & $7-13$ & $14-24$ & $25-27$ \\
\hline 20 & $0-6$ & $7-14$ & $15-25$ & $26-27$ \\
\hline 21 & $0-6$ & $7-15$ & $16-26$ & 27 \\
\hline 22 & $0-6$ & $7-16$ & $17-27$ & \\
\hline 23 & $0-6$ & $7-17$ & $18-27$ & \\
\hline 24 & $0-6$ & $7-18$ & $19-27$ & \\
\hline 25 & $0-6$ & $7-19$ & $20-27$ & \\
\hline 26 & $0-6$ & $7-20$ & $21-27$ & \\
\hline 27 & $0-6$ & $7-21$ & $22-27$ & \\
\hline
\end{tabular}

Tabell 2 viser resultatområder for de ulike endringskategoriene med utgangspunkt $\mathrm{i}$ resultat ved behandlingsstart og tabellen kan brukes som referanse for vurdering av endring. Eksempelvis må en pasient med et utgangspunkt på 17 ved behandlingsstart oppnå et resultat i området $0-6$ for å regnes som frisk. Pasientens tilstand vil regnes som bedre ved resultater i området 7-11, uendret ved resultater i området $12-$ 22 , og som verre ved resultater over 22 .

\section{Vurdering av ufullstendig besvarte skjemaer}

Fra tid til annen oppstår det behov for å sammenfatte spørreskjemaer der pasienter av ulike grunner unnlater å svare på enkeltspørsmål. Dette representerer en praktisk utfordring siden de ulike måtene å sammenfatte spørreskjemaer på normalt forutsetter fullstendig besvarte skjemaer. Ufullstendig besvarte skjemaer gir likevel fortsatt grunnlag for å avgrense og vurdere mulige resultater. Ved kvantitativ sammenfatning angir det faktiske totalresultatet laveste mulige resultat, mens høyeste mulige resultat er gitt ved faktisk resultat + antall ubesvarte $\times 3$. Eksempelvis vil svarene $2_{-} 020_{-} 32$ ha et faktisk resultat på 9 og et mulig resultat $\mathrm{i}$ området 9-18. Dette indikerer mild til moderat depresjon som mer sannsynlig resultat enn alvorlig eller ingen depresjon.

På samme måte er det også mulig å avgrense hva som er aktuelle diagnostiske muligheter ved ufullstendig besvarte skjemaer. I eksempelet med svarene 2 _ $020_{-} 32$ er allerede to kjernesymptomer tilstede og fire symptomer totalt. Dette betyr at disse svarene $i$ det minste passer med diagnostiske kriterier for mild depresjon. Med tre ubesvarte spørsmål ville det være mulig med høyst syv symptomer totalt, noe som ville passe med kriterier for moderat depresjon. Slik sett utelukker dette alvorlig og ingen depresjon som muligheter.

\section{PHQ-9 sammenliknet med aktuelle alternativer}

Fried (2017) viser hvordan spørsmålene i ulike strukturerte kartleggingsverktøy for depresjon i begrenset grad samsvarer på tvers av slike verktøy, noe som potensielt bidrar til ulike resultater i kartlegging av depresjon. PHQ-9 har her en generell fordel av å ha spørsmål som er direkte knyttet til diagnosekriterier for depresjon og kan dermed sammenholdes direkte med disse.

Nasjonale retningslinjer for utredning og behandling av depresjon (Helsedirektoratet, 2009) anbefaler ulike strukturerte kartleggingsverktøy som Montgomery-Assberg Depression Rating Scale (MADRS; Montgomery \& Åsberg, 1979), Beck Depression Inventory-II (BDI-II; Beck, Steer \& Brown, 1996), Geriatric Depression Scale (GDS; Yesavage m.fl., 1982), WHO-5 (Topp, Østergaard, Søndergaard \& Bech, 2015), Hospital Anxiety and Depression Scale (HADS; Zigmond \& Snaith, 1983), Structured Clinical Interview for DSM-IV Axis I Disorders (SCID-I; First, Spitzer, Gibbon, \& Williams, 1996) og Mini International Neuropsychiatric Interview (M.I.N.I.; Sheehan m.fl., 1998).

BDI-II, HADS og SCID-I er rettighetsbeskyttet og av disse har vi kun klart å finne offisiell norsk versjon for BDI-II. I norske versjoner av GDS (Yesavage, 1983) og WHO-5 (World Health Organization, u.å.) er det anbefalt å følge opp med MADRS eller PHQ-9 ved behov for å vurdere depresjon, noe som i praksis 
betyr at GDS og WHO-5 er overflødige for dette formålet. BDI-II, MADRS og M.I.N.I ser slik sett ut til å være de aktuelle alternativene til PHQ-9 i praksis.

Sammenliknet med BDI-II har PHQ-9 fordelene av å være kostnadsfri i bruk, har langt færre spørsmål (BDI-II har 21 spørsmål), alle spørsmål er knyttet til diagnostiske kriterier, og tolkning er ikke kun basert på grenseverdier. Sammenliknet med MADRS har PHQ-9 fordelen av å være laget for selvutfylling, med klart definerte spørsmål og svaralternativer, noe som gjør at psykometriske egenskaper ikke avhenger av en godt trent intervjuer. Sammenliknet med M.I.N.I. er PHQ-9 enkel å sammenholde med diagnostiske kriterier for ICD-10, mens vurdering av depresjon i M.I.N.I. kun er basert på DSM-IV og ikke lar seg tilpasse til ICD-10. Sammenliknet med alle disse alternativene har PHQ-9 fordelen av å ha offisielle oversettelser for ulike språk fritt tilgjengelig på nett, noe som ofte gjør det mulig å la fremmedspråklige pasienter besvare spørsmålene på eget morsmål.

\section{Hva med ICD-11?}

ICD-11 er nå utgitt i en første forberedende versjon (https://icd.who.int/), men det kan fortsatt ta mange år før ICD-11 er innført i Norge og overtar som gjeldende diagnosesystem. Så langt inneholder ICD-11 enkelte mindre endringer $\mathrm{i}$ diagnosekriteriene for depresjon. Redusert energi eller økt trettbarhet vil ikke lenger regnes som et kjernesymptom, noe som vil bidra til bedre harmonisering med DSM-5. Håpløshet innføres som nytt symptom på depresjon. Reed m.fl. (2019) beskriver dessuten at minste antall symptomer som kreves vil økes til 5 - i samsvar med DSM-5 men dette gjenspeiles så langt ikke $\mathrm{i}$ den siste versjonen av ICD-11 på nett (https://icd.who.int/). Slik diagnosekriteriene ser ut så langt, vil PHQ-9 fortsette å være egnet for bruk i klinisk praksis også etter at ICD-11 offisielt tas i bruk.

\section{Sentrale begrensninger ved bruk av PHQ-9 i praksis}

Et godt validert selvrapportskjema med relativt høy sensitivitet og spesifisitet - slik som PHQ-9 - har fortsatt omfattende begrensninger dersom det brukes alene i forsøk på å identifisere klinisk depresjon. Positiv prediktiv verdi er et mål på hvor sannsynlig det er at et positivt testresultat faktisk stemmer. Levis og kollegaer (2019) anslår at for PHQ-9 gir en anbefalt nedre klinisk grenseverdi på 10 en positiv prediktiv verdi på 0,49 ved bruk i primærhelsetjenesten. I til- feller der slik forhåndskartlegging med PHQ-9 indikerer mulig klinisk depresjon vil det derfor være $51 \%$ sannsynlig at dette faktisk ikke stemmer. Gitt en antatt høyere forekomst av depresjon i klinisk psykologisk arbeid i spesialisthelsetjenesten, vil positiv prediktiv verdi her sannsynligvis være noe høyere.

Anslagene til Levis og kollegaer (2019) tilsvarer en negativ prediktiv verdi på 0,98 . Det vil si at i tilfeller der slik forhåndskartlegging ikke indikerer mulig klinisk depresjon vil det være $98 \%$ sannsynlig at dette faktisk stemmer. Oppsummert viser da anslagene til Levis og kollegaer (2019) at PHQ-9 brukt alene $\mathrm{i}$ hovedsak egner seg for å utelukke klinisk depresjon. Mitchell, Yadegarfar, Gill og Stubbs (2016) kom til samme konklusjon og viste samtidig til at PHQ-2 som kun består av de to første spørsmålene på PHQ-9 - med en nedre klinisk grenseverdi på 2 er tilstrekk-

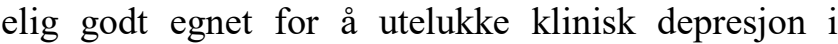
praksis. Dette samsvarer godt med de diagnostiske algoritmene for PHQ-9 - det kreves minst ett topoengs svar på de to første spørsmålene for å oppfylle diagnostiske krav til kjernesymptomer ved depresjon både i DSM og ICD-10.

Det kan være verdt å merke seg at en vurdering basert på kliniske grenseverdier ikke nødvendigvis sammenfaller med vurdering av diagnostiske kriterier. I spørsmål om diagnostikk gir derfor PHQ-9 bedre informasjon når svarene sammenholdes direkte med diagnosekriteriene enn ved å tolke resultatet ut fra de omtrentlige nedre grenseverdiene 5, 10 og 20. I teorien kan forskjellen være stor, noe vi kan illustrere med svarene 113333330 . Med et sammenlagt resultat på 20 kunne disse svarene indikere mulig alvorlig depresjon, men ved å sjekke svarene opp mot diagnosekriteriene ser vi at tilstrekkelig antall kjernesymptomer på depresjon ikke er tilstede. Det eneste kjernesymptomet tilstede er redusert energi eller økt trettbarhet (spørsmål 4), noe som ikke holder for å stille en depresjonsdiagnose. Ved slike svar vil det være naturlig å søke etter andre forklaringer enn depresjon for det høye resultatet. Dette illustrerer en sentral begrensning ved alle strukturerte kartleggingsverktøy som kun bruker grenseverdier for å indikere sannsynlig diagnose - det er ikke gitt at et resultat over en klinisk grenseverdi faktisk representerer et tilfelle der diagnosekriteriene er oppfylt.

I klinisk praksis betyr dette at det er begrenset nytte av å anvende strukturerte kartleggingsverktøy med kliniske grenseverdier for å identifisere depresjon. Siden svarene på PHQ-9 kan sammenholdes direkte med diagnosekriterier for depresjon, vil vi derfor hevde at det er større praktisk nytte av å anvende 
en diagnostisk algoritme i kombinasjon med en helhetlig klinisk vurdering fremfor å anvende kliniske grenseverdier.

En generell begrensning ved strukturerte kartleggingsverktøy er at de ikke er tilstrekkelige for å gjøre en diagnostisk avklaring - det er i tillegg behov for en faglig vurdering av all foreliggende informasjon, inkludert andre mulige forklaringer, for å avgjøre om det foreligger en behandlingstrengende depresjonstilstand. Dette samsvarer også med konklusjonene ovenfor om at PHQ-9 brukt alene i hovedsak egner seg for å utelukke depresjon, men ikke identifisere depresjon. Vi har beskrevet at tilstandsbildet må vurderes opp mot øvrig livssituasjon, og vi har beskrevet hvordan bruk av grenseverdier for å sannsynliggjøre diagnoser i enkelte tilfeller kan være misvisende. Fra eget klinisk arbeid har vi også erfaring med pasienter som besvarer PHQ-9 på en måte som samsvarer med diagnostiske kriterier for alvorlig depresjon, men der dette ikke understøttes av det kliniske inntrykket og øvrig informasjon. I slike tilfeller er det naturlig å undersøke andre forklaringer på pasientens svar.

I likhet med mange andre oversatte kartleggingsverktøy foreligger det så langt ikke noen norsk valideringsstudie av PHQ-9. Av kartleggingsverktøy for depresjon, kjenner vi kun til at det er gjort norsk validering av BDI-II (Aasen, 2001). En rekke faktorer peker mot at PHQ-9 egner seg for bruk under norske forhold likevel. Innholdsmessig fremgår det at spørsmålene på PHQ-9 samsvarer med kriteriene i diagnosesystemene og det er kjent at resultater på PHQ-9 i stor grad sammenfaller med resultater på BDI-II (Titov m.fl., 2011). PHQ-9 er allerede i bruk i Rask psykisk helsehjelp og vi er kjent med at Modum Bad og Folkehelseinstituttet har foretatt en uavhengig oversettelse og tilbakeoversettelse av PHQ-9 (tilgjengelig på https://www.kognitiv.no/). Denne oversettelsen ser ut til å samsvare godt med den offisielle norske versjonen.

Når det gjelder bruk av kartleggingsverktøy for å vurdere endring, er det verdt å påpeke at observasjon av endring i seg selv ikke kan gi noe informasjon om virkning av behandling. Dette gjelder også ved observasjon av eventuell klinisk signifikant endring. Klinisk signifikans er kun en metodisk tilnærming for å vurdere endring, metodikken er ikke egnet til å si noe om virkning (Langkaas, Wampold \& Hoffart, 2018).

\section{Konklusjon}

PHQ-9 er et spørreskjema som er allsidig og anvendelig i vanlig klinisk praksis. Skjemaet er enkelt å besvare, er gratis å bruke og tar kort tid å vurdere. Tabell 3 gir en kort sammenfatning av viktige tall å huske for å vurdere svarene. PHQ-9 kan fint brukes i papirform og kan anvendes både som spørreskjema og intervju. Bruksområdet er både i konsultasjon og mellom konsultasjoner, for forhåndskartlegging av depresjon, diagnostisk vurdering, samt vurdering av endring. For fremmedspråklige pasienter kan skjemaet ofte gis på morsmål.

For depresjonsvurdering, som ofte er en rutineoppgave i klinisk praksis, bidrar PHQ-9 etter vårt syn til raskere, mer fokusert og mer fleksibel kartlegging enn annen strukturert kartlegging av depresjon som med MADRS, M.I.N.I. eller BDI-II. Når det gjelder rutinemessige kliniske oppgaver - som depresjonsvurdering - vil selv små forbedringer som dette kunne gjøre en forskjell i en travel klinisk hverdag.

Tabell 3

Tall å huske for å vurdere svar på PHQ-9.

Tall å huske Beskrivelse

9 Spørsmål 9 gir informasjon om behov for å undersøke selvmordsfare

5, 10, 20 Nedre grenseverdier for rask omtrentlig vurdering av henholdsvis mulig mild, moderat, eller alvorlig depresjon.

1, 2, 4 Spørsmål 1, 2 og 4 angir kjernesymptomer for depresjon i ICD-10.

2, 4, 6, 8 I ICD-10 må minst 2 kjernesymptomer være tilstede og samlet sett minst 4, 6, eller 8 symptomer for henholdsvis mild, moderat, eller alvorlig depresjon (alvorlig depresjon krever alle kjernesymptomene).

$\pm 6, \leq 6 \quad$ For vurdering av klinisk signifikant endring regnes minste målbare forskjell å være på 6 og øvre grense for normal funksjon er på 6 . Ved en målbar nedgang der siste resultat er innenfor området for normal funksjon regnes endringen som klinisk signifikant. 


\section{Referanser}

American Psychiatric Association. (1994). Diagnostic and statistical manual of mental disorders (4th ed.). Washington, DC: American Psychiatric Association.

American Psychiatric Association. (2013). Diagnostic and statistical manual of mental disorders (5th ed.). Washington, DC: American Psychiatric Association.

Beck, A. T., Steer, R. A., \& Brown, G. K. (1996). Beck Depression Inventory-II (BDI-II). San Antonio, TX: Psychological Corporation.

Bekhuis, E., Hartman, T. C. O., Boschloo, L., \& Lucassen, P. L. (2019). A new approach to psychopathology: the example of depression. British journal of general practice, 69(680), 146147. https://doi.org/10.3399/bjgp19X701717

First, M. B., Spitzer, R. L, Gibbon M., \& Williams, J. B.W. (1996) Structured Clinical Interview for DSM-IV Axis I Disorders, Clinician Version (SCID-CV). Washington, D.C.: American Psychiatric Press, Inc.

Fried, E. I. (2017). The 52 symptoms of major depression: Lack of content overlap among seven common depression scales. Journal of affective disorders, 208, 191-197. https://doi.org/10.1016/j.jad.2016.10.019

Helsedirektoratet. (2008). Nasjonale retningslinjer for forebygging av selvmord i psykisk helsevern (IS-1511). Oslo: Helsedirektoratet.

Helsedirektoratet. (2009). Nasjonale retningslinjer for diagnostisering og behandling av voksne med depresjon i primarog spesialisthelsetjenesten (IS-1561). Oslo: Helsedirektoratet.

Jacobson, N.S., \& Truax, P. (1991). Clinical significance: a statistical approach to defining meaningful change in psychotherapy research. Journal of consulting and clinical psychology, 59(1), 12-19. https://doi.org/10.1037/0022-006X.59.1.12

Kroenke, K., Spitzer, R. L., \& Williams, J. B. (2001). The PHQ-9: validity of a brief depression severity measure. Journal of general internal medicine, 16(9), 606-613. https://doi.org/10.1046/j.1525-1497.2001.016009606.x

Kroenke, K., Strine, T. W., Spitzer, R. L., Williams, J. B., Berry, J. T., \& Mokdad, A. H. (2009). The PHQ-8 as a measure of current depression in the general population. Journal of affective disorders, 114(1-3), https://doi.org/10.1016/i.jad.2008.06.026

Langkaas, T. F., Johnson, S. U., Stenshorne, K., Collin-Tiller, C. \& Vrabel, K. R. (2017). Klinisk signifikans i praksis. Tidsskrift for Norsk psykologforening, 54(12), 1160-1167.

Langkaas, T. F., Wampold, B. E., \& Hoffart, A. (2018). Five types of clinical difference to monitor in practice. Psychotherapy, 55(3), 241-254. https://doi.org/10.1037/pst0000194

Levis, B., Benedetti, A., \& Thombs, B. D. (2019). Accuracy of Patient Health Questionnaire-9 (PHQ-9) for screening to detect major depression: individual participant data metaanalysis. $B M J, 365,11476$. https://doi.org/10.1136/bmj.11476

Lichtman, J. H., Bigger Jr, J. T., Blumenthal, J. A., Frasure-Smith, N., Kaufmann, P. G., Lespérance, F., ... \& Froelicher, E. S. (2008). Depression and coronary heart disease: recommendations for screening, referral, and treatment: a science advisory from the American Heart Association Prevention Committee of the Council on Cardiovascular Nursing, Council on Clinical Cardiology, Council on Epidemiology and Prevention, and Interdisciplinary Council on Quality of Care and Outcomes Research: endorsed by the American Psychiatric Association. Circulation, 118(17), 1768-1775. https://doi.org/10.1161/CIRCULATIONAHA.108.190769
Manea, L., Gilbody, S., \& McMillan, D. (2012). Optimal cut-off score for diagnosing depression with the Patient Health Questionnaire (PHQ-9): A meta-analysis. Canadian Medical Association journal, 184(3), E191-E196. https://doi.org/10.1503/cmaj.110829

Mitchell, A. J., Yadegarfar, M., Gill, J., \& Stubbs, B. (2016). Case finding and screening clinical utility of the Patient Health Questionnaire (PHQ-9 and PHQ-2) for depression in primary care: a diagnostic meta-analysis of 40 studies. BJPsych open, 2(2), https://doi.org/10.1192/bjpo.bp.115.001685

Montgomery, S. A., \& Åsberg, M. (1979). A new depression scale designed to be sensitive to change. The British journal of psychiatry, 134(4), 382-389. https://doi.org/10.1192/bjp.134.4.382

National Collaborating Centre for Mental Health. (2018) The Improving Access to Psychological Therapies (IAPT) Manual. England: National Health Service.

National Institute for Health and Care Excellence. (2011). Common mental health problems: identification and pathways to care (Clinical guideline CG123). Hentet fra https://www.nice.org.uk/guidance/cg123

Pfizer. (u.å.). Instructions for Patient Health Questionnaire (PHQ) and GAD-7 Measures. Hentet fra https://phqscreeners.pfizer.edrupalgardens.com/sites/g/files/g10 016261/f/201412/instructions.pdf

Reed, G. M., First, M. B., Kogan, C. S., Hyman, S. E., Gureje, O., Gaebel, W., ... \& Claudino, A. (2019). Innovations and changes in the ICD-11 classification of mental, behavioural and neurodevelopmental disorders. World Psychiatry, 18(1), 3-19. https://doi.org/10.1002/wps.20611

Sheehan, D. V., Lecrubier, Y., Sheehan, K. H., Amorim, P., Janavs, J., Weiller, E., ... Dunbar, G. C. (1998). The MiniInternational Neuropsychiatric Interview (M.I.N.I.): The development and validation of a structured diagnostic psychiatric interview for DSM-IV and ICD-10. The journal of clinical psychiatry, 59(Suppl 20), 22-33.

Smith, O. R. F., Alves, D. E., \& Knapstad M. (2016). Rask psykisk helsehjelp: Evaluering av de første 12 pilotene i Norge. Oslo: Folkehelseinstituttet.

Spitzer, R. L., Kroenke, K., \& Williams, J. B. (1999). Validation and utility of a self-report version of PRIME-MD: The PHQ Primary Care Study. Journal of the American Medical Association, 282(18), 1737-1744. https://doi.org/10.1001/jama.282.18.1737

Strawbridge, R., Young, A. H., \& Cleare, A. J. (2017). Biomarkers for depression: recent insights, current challenges and future prospects. Neuropsychiatric disease and treatment, 13, 1245-1262. https://doi.org/10.2147/NDT.S114542

Titov, N., Dear, B. F., McMillan, D., Anderson, T., Zou, J., \& Sunderland, M. (2011). Psychometric comparison of the PHQ-9 and BDI-II for measuring response during treatment of depression. Cognitive behaviour therapy, 40(2), 126-136. https://doi.org/10.1080/16506073.2010.550059

Topp, C. W., Østergaard, S. D., Søndergaard, S., \& Bech, P. (2015). The WHO-5 Well-Being Index: a systematic review of the literature. Psychotherapy and psychosomatics, 84(3), 167176. https://doi.org/10.1159/000376585

World Health Organization. (u.å.). WHO-5. Hentet fra https://www.psykiatri-regionh.dk/who5/Documents/WHO5 Norwegian.pdf

World Health Organization. (1992). The ICD-10 classification of mental and behavioural disorders. Geneva: World Health Organization. 
World Health Organization. (2017). Depression and other common mental disorders: global health estimates. Geneva: World Health Organization.

Yesavage, J. A. (1983). GDS-geriatrisk depresjonsskala. Hentet fra https://ah-web-

prod.s3.amazonaws.com/documents/GDS.pdf

Yesavage, J. A., Brink, T. L., Rose, T. L., Lum, O., Huang, V., Adey, M., \& Leirer, V. O. (1982). Development and validation of a geriatric depression screening scale: a preliminary report. Journal of psychiatric research,17(1), 37-49. https://doi.org/10.1016/0022-3956(82)90033-4

Zigmond, A. S., \& Snaith, R. P. (1983). The hospital anxiety and depression scale. Acta psychiatrica scandinavica, 67(6), 361370. https://doi.org/10.1111/j.1600-0447.1983.tb09716.x

Aasen, H. (2001). An empirical investigation of depression symptoms: norms, psychometric characteristics and factor structure of the Beck Depression Inventory II. Bergen: Det psykologiske fakultet, Universitetet i Bergen. Hentet fra https://bora.uib.no/handle/1956/1773 